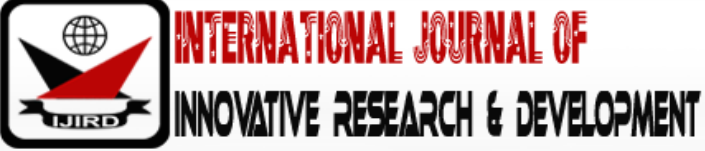

ISSN 2278 - 0211 (Online)

\section{Socio- economic Determinants of Organic Farming Technology among Small Fluted Pumpkin Farmers' in South-South Zone, of Nigeria}

Okonkwo-Emegha. K,
Lecturer, Agricultural Economics and Extension department
Nnamdi Azikiwe University Awka, Nigeria
Umebali. E.E
Lecturer, Agricultural Economics and Extension department
Nnamdi Azikiwe University Awka, Nigeria
Isibor. A.C
Lecturer, Agricultural Economics and Extension department
Nnamdi Azikiwe University Awka, Nigeria

\begin{abstract}
:
This study was conceptualized to examine the socio-economic determinants of organic farming technology among small scale Fluted Pumpkin farmers in south-south zone, of Nigeria. A multi-stage sampling technique was employed in the selection of location and respondents. The data were collected from 720 small scale organic fluted pumpkin farmers. The primary instrument used for data collected was structured questionnaire. Data obtained was analyzed by descriptive statistics. The results of the study showed that the average age of respondents was 37 years. Slightly more than half $(55.30 \%)$ of respondents were females. Also majority (77.80\%) of the organic fluted pumpkin farmers were married, while $97.60 \%$ of respondents were literate. The results further showed that (55.83\%) of respondents were medium sized operators owing average farm sizes of 0.8 hectare. (66.00\%) had a household size of 6 - 9 persons with an average of 7 persons. Majority (81.30\%) had less than 10 years of experience with average experience of 9 years. $(83.20 \%)$ of the respondents were full time operators. The study revealed that $(65.60 \%)$ of the respondents indicated that extension visit were less than 3 times per year. Personal savings (90.91\%) were indicated to be the major source of finance to the respondents. Government and financial institution should make credit available to organic fluted pumpkin farmers at relatively low interest rate. This will serve as incentive to production activities in organic fluted pumpkin producers in South- south zone of, Nigeria.
\end{abstract}

Keywords: Socio-economic, organic farming, technology, small scale, vegetable farmers

\section{Introduction}

Agriculture is a major source of livelihood in Africa where about $80 \%$ of the population practice subsistence or traditional agriculture (Ndungu, Macharia \& Kahuthia-Gathu, 2013). Despite the challenge of meeting the demand for food for the teaming population in Africa, the world average agricultural productivity has dropped over the years due to low skills and inadequate knowledge of technology application Food and Agriculture Organization(FAO,2006).

Organic farming is the use of rich natural fertilizer to maximize biological activity and maintain long-term soil health. It sustains the health of soil ecosystems and as well as minimizes all forms of pollution that may be generated from agricultural practices and maintain vital environmental qualities for people living in the area (FAO, 2006). Organic farming reduces external inputs by refraining from the use of chemical fertilizers, pesticides and pharmaceuticals but depends on natural processes and nutrient cycles related to the environment (Kutama; Abdullahi \& Umar, et al., (2013); Gavino, (2015). Organic production depends mainly on natural system and cycles, cyclic flow of nutrients, on- farm agronomic, biological and mechanical methods such as crop rotation, crop residues, animal manure, off-farm organic waste, compost, green manure (FAO,2006; Ndungu, et al., 2013).

Fluted pumpkin (Telfairia occidentalis) is one of the most important vegetables grown in Nigeria, among the easiest vegetables for cultivation and is always in high demand all year round. The nutritive value and its affordability make it an important diet to the populace (Ndubueze-Ogaraku, 2017). The vegetable is leafy and produces fruit (IFOAM, 2013a). Several studies have been carried out on organic system of vegetable production. A few of these studies examined vegetable farmers' decision to use organic technology in the Southern region of Nigeria (Ordinaka, et al., 2016). The factors influencing the use of organic farming techniques in vegetable production were also investigated. Ndungu, et al., (2013) have established the fact that organic vegetable production system is profitable in Kiambu and Kajiado of Kenya. Despite 
the importance of organic fluted pumpkin production in Nigeria, the socio-economic determinants have not been properly investigated in south-south zone, of Nigeria. This is the gap that this study is filling by focusing on the socio-economic determinants of organic farming technology among small scale vegetable farmers in south-south zone, of Nigeria.

This study specifically stands to:

- Determine the socio-economic characteristics of organic fluted pumpkin farmers in the study

\section{Research Methodology}

The study was carried out in South-South zone of Nigeria. The major part of this zone is dominated by the Niger Delta Region. The zone is made up of six states out of the thirty-six states of the Federal Republic of Nigeria. The six states were Akwa- Ibom, Bayelsa, Cross River, Delta, Edo, and Rivers States. The zone occupies the base of River Niger and its tributaries that empty into the Atlantic Ocean, through the Gulf of Guinea (Ubokudom \& Idiong, 2016). The estimated population of the states in the zone is over 30 million people of different cultural, ethnic and religious beliefs (National Population Commission, 2006).

\subsection{Sampling Techniques and Sample Size}

A multistage random sampling technique was adopted in the selection of states, agricultural zones, local government areas, communities and respondents. In the First stage, fifty percent (50\%) of the states, that is, 3 states in the south -south were randomly selected. These were Cross River, Delta and Rivers state.In the second stage, fifty percent (50\%) of zones in each of the selected states were randomly selected. This gave 2 zones each, giving a total of 6 agricultural zones that were randomly selected. For Cross Rivers State (Calabar zone and Ogoja Zone), Delta State (Delta central and Delta north zone) and Rivers State (zone 1 and zone 11). In the third stage, twenty-five percent (25\%) of LGAS from each of the selected agricultural zones were randomly selected. This gave 6 LGAS each, giving a total of 36 LGAs.In the fourth stage, from each of the selected LGAs twenty-five percent (25\%) of the communities were randomly selected, this gave 4 communities each, giving a total of 144 communities. In the fifth stage, from each of the selected communities 5 respondents each were randomly selected giving a total of 720 respondents that were selected for the study.

\section{Method of Data Analysis}

Objectives i, were realized using descriptive statistics such as frequency distribution table, mean percentage and mode.

\section{Results and Discussions}

\subsection{Socio-economic Characteristics of Small Scale Fluted Pumpkin Organic Farmers in the Study Area}

The socio-economic characteristics of small scale fluted pumpkin farmers were discussed under the following, Age, Sex, Marital status, Educational level, Household size, Years of farming experience, Farm size, Technology type, Mode of Operation, Frequency of extension contact per year, Membership of farmers' organization, Source of finance, off-farm activities and off-farm income.

\begin{tabular}{|c|c|c|c|}
\hline Variable & Frequency & Percentage (\%) & Mean/mode \\
\hline \multicolumn{4}{|l|}{ Age (years) } \\
\hline 20 and below & 6 & 0.80 & \\
\hline $21-30$ & 88 & 12.23 & \\
\hline $31-40$ & 475 & 66.00 & 37 years \\
\hline $41-50$ & 149 & 20.07 & \\
\hline 51 and above & 2 & 0.30 & \\
\hline \multicolumn{4}{|l|}{ Sex } \\
\hline Male & 322 & 44.7 & \\
\hline Female & 398 & 55.3 & Female \\
\hline \multicolumn{4}{|l|}{ Marital status } \\
\hline Single & 103 & 14.3 & \\
\hline Married & 560 & 77.80 & Married \\
\hline Widow/widower & 20 & 2.80 & \\
\hline Divorced & 37 & 5.10 & \\
\hline \multicolumn{4}{|l|}{ Educational level } \\
\hline No formal education & 17 & 2.40 & \\
\hline Primary & 2 & 0.30 & Tertiary \\
\hline Secondary & 175 & 24.30 & \\
\hline Tertiary & 526 & 73.00 & \\
\hline \multicolumn{4}{|l|}{ Farm size } \\
\hline 0.5 and below & 178 & 24.73 & \\
\hline $0.6-1.0$ & 402 & 55.83 & 0.8 hectare \\
\hline Above 1.0 & 140 & 19.44 & \\
\hline \multicolumn{4}{|l|}{ Household size } \\
\hline Less than 2 & 11 & 1.50 & \\
\hline
\end{tabular}




\begin{tabular}{|c|c|c|c|}
\hline Variable & Frequency & Percentage (\%) & Mean/mode \\
\hline $2-5$ & 125 & 17.40 & 7 persons \\
\hline $6-9$ & 475 & 66.00 & \\
\hline 10 and above & 109 & 15.10 & \\
\hline Years of Experience & & & \\
\hline Below 10 & 585 & 81.30 & \\
\hline $10-15$ & 104 & 14.40 & \\
\hline $16-21$ & 21 & 2.90 & 9 years \\
\hline Above 21 & 10 & 0.14 & \\
\hline Mode of operation & & & \\
\hline Full time & 599 & 83.2 & \\
\hline Part time & 121 & 16.8 & \\
\hline $\begin{array}{l}\text { Frequency of extension contact } \\
\text { per year }\end{array}$ & & & \\
\hline Less than 3 times & 472 & 65.60 & \\
\hline 3-4 times & 235 & 32.60 & \\
\hline 5 times and above & 13 & 1.80 & \\
\hline $\begin{array}{c}\text { Membership of farmers' } \\
\text { organization }\end{array}$ & & & \\
\hline Members & 370 & 51.40 & \\
\hline Non members & 350 & 48.60 & \\
\hline Source of finance & & 5.30 & \\
\hline Cooperative & 38 & 91.90 & \\
\hline Personal savings & 662 & 0 & \\
\hline Banks & 0 & 2.8 & \\
\hline Isusu & 20 & & \\
\hline Off- farm activities & & 56.00 & \\
\hline Trading & 403 & 11.50 & \\
\hline Teaching & 83 & 7.20 & \\
\hline Hair dressing & 52 & 5.10 & \\
\hline Politics & 37 & 6.70 & \\
\hline Mason & 48 & 13.50 & \\
\hline Catering & 97 & & \\
\hline Off-farm income & & 53.60 & \\
\hline Less than $\# 100,000$ & 386 & 15.30 & \\
\hline$\# 100,000$ - \#200,000 & 110 & 29.40 & \\
\hline \#201,000 - \#300,000 & 212 & 0.6 & \\
\hline \#301,000 - \#400,000 & 4 & 1.1 & \\
\hline Above \#400,0008 & $\mathrm{X}$ & \#142794.03 & \\
\hline
\end{tabular}

Table 1: Distribution of the Socio-Economic Characteristics of the Respondents ( $\mathrm{N}=720)$ Source: Field Survey, 2018

\subsubsection{Age}

The results of age distribution showed that majority (86.07\%) of the respondents were within the age bracket of 31-50 years, see (Table 1). Within this age distribution, the respondents are expected to be active on farm activities and more responsive to organic fluted pumpkin production. It implied that fluted pumpkin farmers were within the ages known as economically productive age and it indicates a better ground for small scale fluted pumpkin in the study area. Organic fluted pumpkin farmers developmental programme should be planned at this age bracket for sustainability, high yield and good profit. The average age of fluted pumpkin farmers in the study area was 37years. The farmers are still young and are capable of impacting positively on fluted pumpkin production. This result agrees with the findings of (Ugbajah, et al.,2015) that reported the dominance of the age bracket of 31-50 years of fluted vegetable farmers in Onitsha Southeast zone, Nigeria. They stated that age is regarded as an important variable because it influences people's attitude, skill and aspiration.

\subsubsection{Sex}

The result showed that slightly more than half (55.3\%) of the respondents were female and fairly good proportion $(44.70 \%)$ are males (Table 1). This implied that the type and quality of work carried out by an individual can be influenced by the sixths result showed that females were more in organic fluted pumpkin production in the study area. Vegetable 
production is not tedious this could be the reason women are more in vegetable farming. This result agrees with the findings of Ndubueze-Ogaraku,(2017) who reported that women dominated the farming population in crop production. Also in line with the study of (Ugbajah, et al.,2015) which stated that organic agriculture support women activities and enhances their contribution to be visible, give economic opportunities such as low production cost.

\subsubsection{Marital Status}

Majority (77.80\%) of the respondents were married, fair proportion (14.3\%) were single see (Table 1). This implied that married farmers can settle down and coordinate their business. Married farmers inorganic fluted pumpkin production have the benefit of family labor than the unmarried. They could combine their effort for high profit. This result is in line with the report of Obianuju \& Asa (2015) who reported that good number of small scale farmers are married and have better performance and efficiency in vegetable production.

\subsubsection{Educational Level}

Majority (97.60\%) of respondents were literate see (Table 1). A fairly good proportion (24.30\%) of the literate small scale organic fluted farmers had completed secondary education, $(0.30 \%)$ had primary education and $(73.00 \%)$ had tertiary education, while $(2.40 \%)$ had no formal education. This indicates that high education attainment will motivate farmers for organic technology adoption and also promote profit in farming activities. It shows that small scale fluted pumpkin farmers would not have difficulties in the training and embracing modern agricultural technologies and innovations. And also that education level of the organic fluted pumpkin farmers could influence attitude to production and increase skills for high profit. Gordon and Craig (2011) reported also that education increase skill level. This finding is in line with (Ugbajah, et al., 2015) who reported also that $90 \%$ of the vegetable farmers had some formal education which indicates good understanding and adoption of improved agricultural skills and technologies.

\subsubsection{Farm Size in Hectare}

Slightly more than half $(55.83 \%)$ of the respondents were medium size operators of (0.6-1.0) hectare. The average farm size of operation was 0.8 hectare in the study area see (Table 1). Fair proportion (24.73\%) were small size operators between ( 0.5 and below) hectare, $(19.44 \%)$ of the respondents were large scale operators of above 1.0. This implied that organic fluted pumpkin farmers in the study area were small scale producers. This might be attributed to limited farm land, problems of fragmentation of land and lack of credit or non-availability of credit. This finding agrees with Olowa\& Olowa (2016) who reported that farm sizes are fragmented and small-scaled in Nigeria having less than 2 hectares. The result is also in line with the report of (Ugbajah, et al., 2015) that majority (98\%) of organic farmers in Nigeria are small-holder with 0-2 hectares of land.

\subsubsection{Household Size}

Majority (66.00\%) had a household size of 6 - 9 persons, 17.40\% had the household size range of 2-5 while $15.10 \%$ had the household size range of 10 and above. The average household size was 7 persons in the study area (Table 1). This shows that most fluted pumpkin farmers have relatively large household sizes. The high use of family labor justifies large household size. Family labour is expected to be enjoyed in this large size. This implied that the engagement of family labour will reduce cost to an extent, thereby increasing the profitability. This result agrees with the findings of Ndubueze-Ogaraku, (2017) who reported that average household size of small scale farmers was within 6-10 persons.

\subsubsection{Farming Experience}

Majority (81.30\%) of the respondents were within the years of farming experience of below 10 years. Result showed that $14.40 \%$ of the respondents were within the years of farming experience of $10-15$ years, $2.9 \%$ were within the range of $16-21$ years of experience, while only $0.14 \%$ were above 21 years of farming experience. The average farming experience was 9 years in the study (Table 1). The result implies that the higher the years of farming experience the greater use of skills and sustenance for efficiency in production. It also showed that the years of experience can also lead to profitability and good return. It indicates that fluted pumpkin farmers have the strength of maximizing their output and profits at minimum cost. It agrees with the findings ofOlowa \& Olowa (2016) who reported that farming experience of about ten years provide necessary skills for high productivity and efficiency.

\subsubsection{Type of Technology}

Majority of the respondents (77.80\%) were organic fluted pumpkin farmers, while $22.20 \%$ were inorganic (conventional) fluted pumpkin farmers. The result implies that organic producers dominated the study area. The result disagrees with the findings of (Nduagu, et.al., 2013) who reported that conventional farming is dominant in Kiambu country.

\subsubsection{Mode of Operation}

Majority (83.20\%) of the respondents were full time operators and fair proportion (16.80\%) were part time organic fluted pumpkin farmers. This implies that full time concentration is given to organic farming in fluted pumpkin production. This agrees with the findings of (Obinaju \& Asa, 2015) who reported that small scale vegetable farmers are basically full time operators. 
Majority (65.60\%) of the respondents were in contact with extension workers for less than three times per year, while $32.60 \%$ had extension contact of 3-4 times a year. Results further showed that $1.80 \%$ contact of 5 times and above. This result implies that extension services were poor in the study area and this could affect the level of adoption and profitability. This result agrees with the findings of K'esit, et.al., (2015) who reported that vegetable farmers in Cross River state were not having an adequate extension contact with agricultural extension services.

\subsubsection{Membership of Farmers' Organization}

The result showed that more than half (51.40\%) of the respondents were members of farmers' organization while $48.60 \%$ were not members. This reveals that most of the organic fluted pumpkin farmers belong to farmers' organization where they could possibly be exposed to innovations by interaction with others. Membership of famer's organization will enable the farmers to train and understand the benefits of technology acquisition for high yield and profitability. This result agrees with the report of Agric- view, (2018) who reported that many farmers belong to various organizations.

\subsubsection{Source of Finance}

Personal savings was the source of finance of majority (91.9\%) of the respondents. Results also showed that $5.3 \%$ of the farmers sourced their finance from the cooperatives while $2.80 \%$ obtained their finance from isusu. This implies that farmers are hardworking to enable good savings for the farming season. This result agrees with the report of Agric-view (2018) that personal savings through agricultural activities and off- farm income promote production.

\subsubsection{Off-farm Activities}

Slightly more than half (56.00\%) of the respondent practice trading as off-farm activities, $11.50 \%$ of the farmers were into teaching, $7.20 \%$ were into hair dressing. Results showed that $13.5 \%$ were into catering, $6.70 \%$ of the respondents were into mason and $5.10 \%$ of farmers were into politics. It implies that some of the farmers have alternative sources of income to obviate risk and uncertainties in agricultural activities. It indicates diversification of activities to generate more money for production. This agrees with the report ofAgri-view (2018) that some of the farmers have more than one minor occupation as means of sustenance.

\subsubsection{Off-farm Income}

The results of the respondents of off-farm income showed that more than half (53.60\%) of the respondents had less than $\mathrm{N1} 100,000,29.4 \%$ had between $\mathrm{N} 201,000$ - N300,000 and also 15.30\% of farmers had between N100,000N200,000 while 1.70\% of respondents had between $\mathrm{N} 301,000$ and above. Off-farm income act as an important means of overcoming credit challenges confronting the small scale farmers in Nigeria, and other developing countries (Reardon et al., 2007). It indicates that off-farm income acts as a substitute to borrowed capital in rural area where credit market is not available. This implies that organic fluted pumpkin farmers in the study area practiced subsistence agriculture. This is in line with the findings of (Ugbajah, et al., 2015) who stated that vegetable famers operate at a normal income of between 51,000-100,000 naira that put them above poverty level.

\section{Conclusions}

The findings of the study showed that socio-economic characteristics of farmers was a determinant to organic farming technology in the study area.

Firstly, average age of the farmers were 37years, with varying level of literacy dominated the surveyed farmers, (55.30\%) of the respondents were female, (77.80\%) of the surveyed farmers were married, the average hectare were 0.8 , the average household size were seven persons and the average years of experience were 9 years, $(77.80 \%)$ were into organic technology, (83.20\%) were full time operators, frequency of extension contact per year (less than 3 times were $(65.60 \%)$, most of the farmers (51.40\%) were members of farmers' organization, (91.90) support themselves with personal finance, (56.00\%) engaged in trading for off-farm activities and the mean off-farm income was \$142,794.03.

\section{Recommendations}

- Government and financial institution should make credit available to organic fluted pumpkin farmers at relatively low interest rate. This will serve as incentive to production activities in organic fluted pumpkin producers in Southsouth zone of, Nigeria.

- The market price of fluted pumpkin pod and leaves should be encouraging to motivate organic fluted pumpkin farmers,

- The Return on pod were major determinants of profitability, farmers should pay serious attention to pod production, to enhance more profit.

\section{References}

i. Agric- View (2018). On line publication, http/ / www.agric view.org.ng

ii. Food and Agriculture Organization. (FAO, 2006). World Agriculture. Towards 2030/ 2050. FAO, Rome.

iii. Gavino, I. P.U. (2015). Organic Farming Technologies. National Soil and Water Resources Research Development Center for HillylandPedo-Ecological Zone. In:the 12th National Organic Agriculture Congress, held at SMX Convention Center, SM Bacolod City of Philippines from 25th November to 27th,2015. 
iv. K'esit, K.N., Out, W.I., Idaresit, U. U and Okoh, T.U. (2014). Factors influencing the use of organic manure by Female Vegetable Farmers in Cross River State, Nigeria. Asian Journal of Agricultural Extension Economics \& Sociology. 4(1): 21-28,2015; Article no AJACES. 2015.003.

v. Kutama, A.S., Abdullahi, M.A., Umar, S., Binta, U.B., \&Ahmad,M.K. (2013): Organic Farming in Nigeria: problems and future prospects. Global Advanced Research Journal of Agricultural Science, Vol.2(10) ISSN: 2315-5094). Pp 256262. http:// garj.org/ garjas/ index.htm.

vi. Ndubueze-Ogaraku, M. E: (2017): A comparative Study on Fluted Production in the Niger Delta,

vii. Nigeria.Journal of Biology, Agriculture and Healthcare, vol. 7, No 14. ISSN 2224-3208 (Paper).www.iiste.org

viii. Ndungu, S. K., Macharia, I. \&Kahuthia-Gathu, R. (2013). Analysis of profitability of organic vegetable production system in Kiambu and Kajiado countries of Kenya. African Crop Science Conference Proceedings, Vol.11. ISSN 1023 -070X, pp. 605- 611.

ix. Obianuju, L.C., \& Asa, U.A., (2015). Economic Analysis of Vegetable (Telfairia Occidentalis Hook F.) Production Among Farming Households in Ibiono Ibom Local Government Area of Akwa Ibom State, Nigeria. European Journal of Agricultural and Forestry Research. Vol.3, No. 4, pp. 17-24, Septermber. ISSN 2054-6319 (Print) ISSN 2054 - 6327 (online).

x. Olowa, O. W. \& Olowa, O.A. (2016). Assessment of Economic Viability of Fluted Pumpkin Farming in Ikorodu LGA, Lagos State. World Rural Observation. Vol. 8 (1), pp 3-8. ISSN 1944 -6543 (Print); ISSN: 1944 - 6551. http:// www.sciencepub.net/ rural.

xi. Ordinaka,C.F., Anayor, B.O., Ogbonnaya, G.H., Abasi, D.S.\&Eket, M.O. (2016). A study of vegetable farmers' decision to use poultry litter in the southern region of Nigeria. African Journal of Agricultural Economics and Rural Development. ISSN:2375-0693 Vol.4(7), pp.446-451.

xii. Oyewole, M.F. (2015). Gender Involvement in Ecological organic crop farming in Ogun State. Achieving social and economic development through ecological and organic Agricultural Alternative Scientific Track proceeding of the $3^{\text {rd }}$ African organic conference. 5-9 October 2015 in Lagos Nigeria.

xiii. Reardon, T., Stamoulis., K and Pingal, P. (2007)." Rural Nonfarm Employment in Developing Countries in era of Globalization." Agricultural Economics.

xiv. Ubokudom, E. O. \&Idiong C.I. (2016). Factors influencing Adoption of organic vegetable farming among farm households in south-south Region of Nigeria. American - Eurasian Journal of Agricultural\& Environmental Science. 16 (5), ISSN 1818 - 6769.

xv. Ugbajah, M.O., Sand Chidebelu, C. O., Uzoegbunam, E.N, Azifuaku. (2015). Financing of Organic Farming Activities Among Vegetable Farmers in Onitsha Agricultural Zone Southeast Zone, Nigeria. International Journal of Agriculture, Forestry and Fisheries. Vol. 3 (6) 2015, pp 213-217. 